\title{
THE EFFECT OF SOCIAL CAPITAL ON THE QUALITY OF LIFE OF EMPLOYEES IN WORKING ENVIRONMENT
}

\author{
Budi Yulianto',2), Bhisma Murti3), Hartono4), \\ Muhammad Masykuris) \\ 1)Doctoral Program in Enviromental Sciences, Universitas Sebelas Maret \\ ${ }^{2}$ School of Health Polytechnic, Ministry of Health Surabaya \\ 3) Masters Program in Public Health, Universitas Sebelas Maret \\ 4)Faculty of Medicine, Universitas Sebelas Maret \\ ${ }^{5)}$ Faculty of Educational Sciences, Universitas Sebelas Maret
}

\begin{abstract}
Background: The textile industry has grown rapidly in Indonesia. As many as 2,900 textile industries spread throughout the country. Yet half of the textile industry employees work in weaving sections that have high noise intensity. This can lead to stress and behavioral changes, which can ultimately affect the quality of life of employees. Conceptually, the quality of the social environment in the workplace is influenced by the quality of social interaction and norms in the workplace. The quality of employees' lives is influenced by physical, psychological, and environmental factors, including employee freedom. This study aimed to analyze the influence of social capital on the quality of life of employees working in a noisy environment with high intensity in the textile industry in Karanganyar, Central Java.

Subjects and Method: This was a cross-sectional study conducted at Kusuma Hadi textile industry, Karanganyar, Central Java. A sample of 250 employees (weaving 1, weaving 2, and administration) were taken for this study by simple random sampling. The independent variables were social capital, social stressors, and behavioral changes. The dependent variable was quality of life. The data were collected by questionnaire and analyzed by Structural Equation Modelling (SEM). Results: Quality of life was affected by behavioral changes $(b=0.67, p<0.05)$, and behavioral change was influenced by social stressor $(b=0.73, p<0.05)$. Social stressor was influenced by social capital $(b=0.44 ; \mathrm{p}<0.05)$.

Conclusion: Social capital indirectly affects the quality of life of employees working in high-intensity noise environment through social stressor and behavioral changes.
\end{abstract}

Keywords: quality of life, social capital, noise environment, textile industry, employee

Correspondence:

Budi Yulianto. School of Health Polytechnic, Ministry of Health Surabaya, East Java. Email: bbudi_yulianto@yahoo.co.id. 